\title{
Efficacy of plasma rich in growth factor used for dry socket management: a systematic review
}

\author{
Ji Liang Xu ${ }^{1,2}$, Rong Xia ${ }^{1}$
}

\begin{abstract}
${ }^{1}$ Department of Stomatology, the Second Hospital of Anhui Medical University, 678 Furong Road, Hefei 230601, People's Republic of China

${ }^{2}$ Department of Stomatology, Lianhua community health service centre of the Second Hospital of Anhui Medical University, 736 lianhua Road, Hefei 230601, People's Republic of China
\end{abstract}

Correspondence:

No. 678 Furong Road

Hefei 230601

People's Republic of China

464504471@qq.com

Received: $31 / 01 / 2019$

Accepted: 16/09/2019

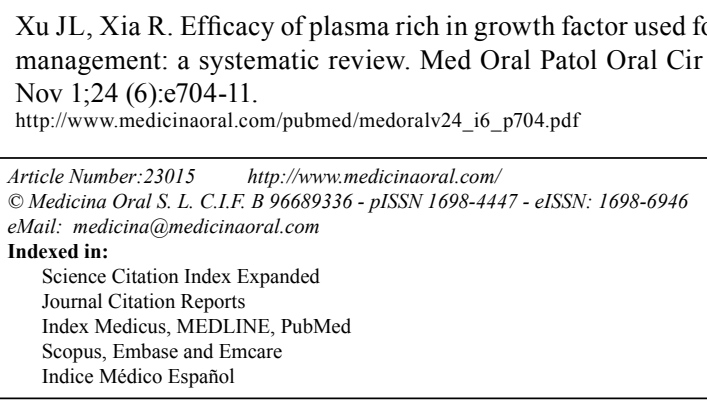

\begin{abstract}
Background: The main aim of this systematic review was to assess the dry socket management using plasma rich in growth factor (PRGF) in terms of pain relief, alveolar fossa healing, inflammation, the incidence of dry socket. Material and Methods: PubMed, Cochrane Library, Elsevier Science Direct, China Biology Medicine (CBM), China National Knowledge Infrastructure (CNKI) and VIP database were searched for the related articles without language limitation. Two reviewers independently searched and evaluated relevant studies. This review has been registered in the website PROSPERO (CRD42018087252).

Results: 28 articles were retrieved on PubMed and 98 on other electronic databases in the initial search. In the end, 4 randomized controlled trials (RCTs) were included, with a total of 139 patients enrolled. The descriptive results indicated that the use of PRGF may help reduce pain and inflammation after tooth extraction. To some extent, it is beneficial to the management of dry socket after extraction.

Conclusions: Quality assessment indicated all the included studies were judged to be at high risk of bias with low quality. Hence, it was impossible to make a recommendation for clinical use of PRGF based on the current evidence. Clearly, a multicenter clinical randomized controlled trial is needed urgent to evaluate the safety and efficacy of PRGF for dry socket management.
\end{abstract}

Key words: Plasma rich in growth factor, PRGF, dry socket, systematic review. 


\section{Introduction}

The unscientific term "dry socket" also called alveolar osteitis, was first proposed by Crawford in 1896. Dry socket is characterized by an extraction alveolus lack of a blood clot and along with sudden intense, lancing and radiated pain after 2-3 days following tooth extraction in and around the extraction sites, accompanying strong smell of corruption (1-4). The most common findings in clinical examinations are the extraction sockets without any blood clots and sometimes part blood clots with spoilage and necrosis in the extraction sockets (5). On account of the different diagnostic criteria used, the incidence of dry socket reported in the literature is inconsistent. It is reported that the incidence of dry socket is about $20 \%-35 \%$ after impacted mandibular third molars extraction $(2,6,7)$, whereas its occurrence for all extraction is from $3 \%$ to $5 \%(8,9)$.

Patients infected with dry socket after extraction often seek urgent treatment for severe pain, halitosis and dysgeusia (bad taste) (4). To date, various modalities were proposed for dry socket management. These treatments included topical using pain reducing dressing such as zinc oxide eugenol (ZOE) dressing (10-13) and chitosan dressing (14), topical or systemic antibiotics agents, and wound healing promoting drugs for example exogenous tretinoin acid (15), honey $(16,17)$,herbal exacts (18). Surgical debridement treatment for dry socket, refers to some or all of the following procedures: block anesthesia for the socket, debridement, irrigation and placing a dressing with or without sutures (19).

Autologous platelet concentrates (PCs) are being widely used in the field of dental and tissue regenerative medicine (20-22). PRGF is a leukocyte-free, of standard composition and dosage, $100 \%$ autologous platelet-rich plasma (PRP) (23-25). However, PRGF is regarded as a secure and optimized product that avoids many of the limitations of using other PRPs (26). It has been reported that PRGF has been displayed tissue regeneration in implant placement and the maxillary sinus membrane damage repair (27-31) and antibacterial activity $(32,33)$ in a series of post-operations in oral surgery.

There were conflicting results for the efficacy of PRGF used for dry socket management following the third molars extraction $(12,26,34,35)$, due to small sample size, short follow-up and inconsistent outcome variables.

The main aim of this systematic review was to assess the dry socket management using PRGF in terms of pain relief, alveolar fossa healing, inflammation, the incidence of dry socket.

\section{Material and Methods}

This systematic review was performed in agreement with PRISMA statement guidelines (36). The protocol and methods used were registered in website PROSPERO (CRD42018087252), which is an international prospective register of systematic reviews.
- Search methods and key words

Systematic and comprehensive retrieval was carried out in the following electronic database: PubMed, Cochrane Library, Elsevier Science Direct, China Biology Medicine (CBM), China National Knowledge Infrastructure (CNKI) and VIP database (Chinese scientific journal database). The search strategy on PubMed is as follows: (dry socket OR alveolar osteitis OR fibrinolytic alveolitis OR alveolitis sicca dolorosa OR localized osteomyelitis OR delayed extraction wound healing OR localized osteitis alveoli OR septic socket OR necrotizing socket OR tooth extraction* OR teeth extraction* OR dry socket [Mesh]) AND (plasma rich in growth factor* OR plasma rich growth factor* OR PRGF). In other electronic databases, the mesh terms search was not used.

In addition, a manual search was performed to find related articles in the following publications: British Journal of Oral and Maxillofacial Surgery, International Journal of Oral and Maxillofacial Surgery, Journal of oral and maxillofacial surgery, Oral Surgery, Oral Medicine, Oral Pathology and Oral Radiology, European Journal of Dentistry, Journal of Dental Research, Journal of the American Dental Association, Australian Dental Journal, Oral and Maxillofacial Surgery, British Dental Journal, Oral Diseases, Indian Journal of Dental Research.

Besides, a manual search and screening of the references reported in the studies identified was also complemented. The above retrieval process was performed by two reviewers independently (XJL and LJT). An upper date limit of 26 March 2019 was applied, with no lower date limit. There was no language restriction.

Inclusion and exclusion criteria

Studies with the following characteristics were included: 1-Population: studies of humans that included adult patients who had undergone extractions of one or more teeth; 2-Intervention: application of PRGF to post extraction sockets; 3-Comparison: application of a placebo or other treatments to post extraction sockets; 4-Outcome: pain relief, alveolar fossa healing, inflammation, the incidence of dry socket; 5-Study design: only randomized clinical trials (RCTs) were included, with the other factors matched between the groups.

Exclusion criteria: 1-reviews, editorials, case reports, letters and conference abstracts; 2 -animals studies were excluded; 3 -studies without control group were excluded.

- Data extraction

The data from all included studies were extracted independently by two reviews (XJL and LJT) using predefined data extraction form. The following information was extracted from each study (when available): first author, publication year, location, design method, characteristics of population, smoking status, oral con- 
traceptive administration, extraction sites, intervention characteristics, follow-up period, outcome measures.

- Quality assessment

The methodological quality of all selected studies were evaluated independently by two reviewers (XJL and LJT), and these were cross-checked. Disagreements between the two reviewers were resolved by consensus with a third reviewer (XR). Quality assessment tool for randomized controlled trials was on the basis of the risk of bias assessment scale recommended in the Cochrane handbook for systematic reviews. The classification of the risk of bias potential was based on the following criteria: sequence generation, allocation concealment, blinding of participants and personnel, blinding of outcome assessment, incomplete outcome data addressed, selective reporting, and other sources of bias. If all assessment items are reported as 'yes', the study is judged to be at low risk of bias. If one or more items are reported as 'unclear', the study is considered to be at moderate risk of bias. If one or more items are reported as 'no', the study is regarded as being at high risk of bias.

\section{Results}

- Study selection

126 titles were retrieved in the initial search. All the titles were poured into the professional document management NoteExpress (a Chinese software similar to EndNote, http://lib.ahmu.edu.cn/). Its duplicate checking function excluded 8 titles. After duplicate removal, 118 titles were screened by title and abstract, leading to 94 titles excluded. Moreover, 24 potentially eligible titles were retrieved through the consulting of reference lists of included studies. Finally, only 4 articles were included for the qualitative synthesis (Fig. 1).

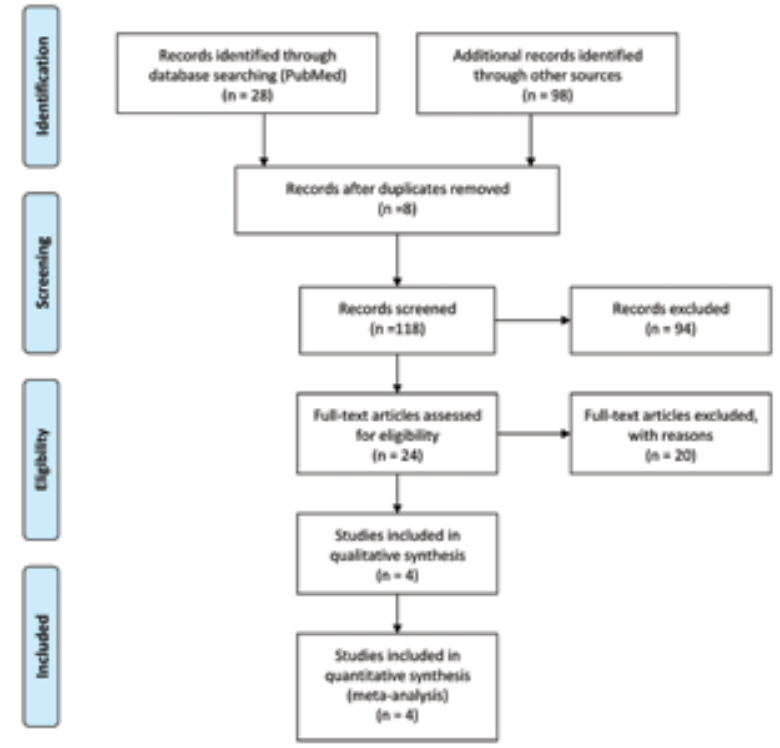

- Characteristics of all the included studies

Basic details of all the selected studies were shown in Table 1. All the four studies were RCTs, two of which adopted split-mouth design. A total of 139 patients were enrolled in the four studies. The duration of the study was 8 years, from 2010 to 2018. Two studies were carried out in Europe (UK, Italy), one in India and the other in Iran. Two studies included smokers, but did not detail the smoking status. Only one study included women taking oral contraceptives. Not every article provided information about the number of sockets and the extraction sites. The follow-up periods varied among the four articles, with the shortest of one day and the longest of 15 days. All clinical outcome measures in four studies comprised pain relief and healing situation.

- Quality assessment

Every study was evaluated for potential risk of bias. The results of the quality assessment of all the four studies was presented in Table 2. Unfortunately, all included studies were judged to be at high risk of bias with low quality. Kappa statistic value for the inter-reviewer agreement was 0.851 , which indicates "almost perfect" based on Landis and Koch scale (37).

- Quantitative synthesis

The results of studies included for analysis were presented in Table 3 . This systematic review did an attempt to conduct a meta-analysis by virtue of STATA 12.0 software, which could summarize the extracted data from the included studies, enhancing statistical power. However, based on the above fact that too small sample, low-quality literature and high heterogeneity among the four studies, a meta-analysis was considered to be inappropriate here.

- Qualitative description

Pain relief

VAS scores system of $10 \mathrm{~cm}$ was used for evaluation of pain level in all included studies. Mozzati et al. found that the pain level was lower for PRGF sites than for control sites at all times examined (1d to 7d), however, this difference was statistically significant only at $7 \mathrm{~d}$ with $p$ value of $<0.05$. Haraji et al. reported that the intensity of post-extraction pain in PRGF group was significantly less than that in control group with $\mathrm{p}$ value of $<0.00$ at each post-extraction day (2d, 3d, 4d). Pal et al. noted that pain reduction level is more rapid in zinc oxide eugenol group than in PRGF group and saline irrigation group at $1 \mathrm{~d}, 2 \mathrm{~d}, 3 \mathrm{~d}, 7 \mathrm{~d}(p<0.001)$, but the change is no significant at $15 \mathrm{~d}$ in all the groups. Contrary to the above, King et al. indicated that there were not statistically significant for the pain level between PRGF and Alvogyl ${ }^{\circledR}$ group at $3 \mathrm{~d}$ and $7 \mathrm{~d}$, even though the VAS value of the PRGF group was low.

Fig. 1: PRISMA flow chart of the search strategy. 
Table 1: Characteristics of all the selected studies.

\begin{tabular}{|c|c|c|c|c|}
\hline Author & Mozzati et al. & Haraji et al. & Pal et al. & King et al. \\
\hline Publication year & 2010 & 2012 & 2013 & 2018 \\
\hline Location & Italy & Iran & India & $\mathrm{UK}$ \\
\hline Design method & RCT,SM & RCT, SM & RCT & RCT \\
\hline Number of patients & 16 & 40 & 45 & 38 \\
\hline Number of sockets & 32 & 80 & $\mathrm{NM}$ & 44 \\
\hline $\begin{array}{l}\text { Mean age (range), } \\
\text { years }\end{array}$ & $22.5(18-35)$ & $22.10(18-45)$ & $\begin{array}{l}\text { G1:31.05(NM) } \\
\text { G2:32.57(NM) } \\
\text { G3:31.98(NM) } \\
\end{array}$ & $\begin{array}{l}\mathrm{G} 1: 41.10(\mathrm{NM}) \\
\mathrm{G} 2: 39.40(\mathrm{NM})\end{array}$ \\
\hline $\begin{array}{l}\text { Number (females/ } \\
\text { males) }\end{array}$ & NM & NM & $\begin{array}{l}\mathrm{G} 1: 9 / 6 \\
\mathrm{G} 2: 8 / 7 \\
\mathrm{G} 3: 9 / 6\end{array}$ & $\begin{array}{l}\mathrm{G} 1: 11 / 11 \\
\mathrm{G} 2: 9 / 13\end{array}$ \\
\hline Smoking population & NM & 18 patients & Excluded & 13 patients \\
\hline OC administration & NM & 10 patients & NM & NM \\
\hline Extraction sites & $\begin{array}{l}\text { Mandibular third } \\
\text { molar }\end{array}$ & $\begin{array}{l}\text { Maxillary or mandibu- } \\
\text { lar third molar }\end{array}$ & NM & $\begin{array}{l}\text { Anterior, premolar, and } \\
\text { molar }\end{array}$ \\
\hline Group situation & $\begin{array}{l}\text { G1:PRGF } \\
\text { G2:control }\end{array}$ & $\begin{array}{c}\text { G1: PRGF } \\
\text { G2: placebo }\end{array}$ & $\begin{array}{l}\text { G1: PRGF with gelatin } \\
\text { sponge } \\
\text { G2: zinc oxide eugenol } \\
\text { G3:saline irrigation }\end{array}$ & $\begin{array}{c}\text { G1: PRGF } \\
\text { G2: Alvogyl }\end{array}$ \\
\hline Follow-up & $1,2,3,4,5,6$ and 7 days & $2,3,4$ and 7 days & $1,2,3,7$ and 15 days & 3 and 7 days \\
\hline Outcome measures & $\begin{array}{l}\text { Pain, inflammation, } \\
\text { healing }\end{array}$ & DS, pain, healing & Pain, healing & $\begin{array}{l}\text { Pain, swelling, } \\
\text { bleeding, bruising, } \\
\text { inflammation,exposed } \\
\text { bone, halitosis, dysgeusia }\end{array}$ \\
\hline
\end{tabular}

$\mathrm{RCT}=$ randomized controlled trial; $\mathrm{SM}=$ split-mouth; $\mathrm{DS}=$ dry socket; $\mathrm{NM}=$ not mentioned; $\mathrm{OC}=$ oral contraceptive; $\mathrm{G} 1=$ test group; $\mathrm{G} 2=\mathrm{control}$ group; $\mathrm{G} 3=$ other treatments group.

Table 2: Results of quality assessment.

\begin{tabular}{|c|c|c|c|c|c|c|c|c|}
\hline Author & $\begin{array}{c}\text { Random } \\
\text { sequence } \\
\text { generation }\end{array}$ & $\begin{array}{c}\text { Allocation } \\
\text { concealment }\end{array}$ & $\begin{array}{c}\text { Blinding of } \\
\text { participants } \\
\text { and } \\
\text { personnel }\end{array}$ & $\begin{array}{c}\text { blinding } \\
\text { of outcome } \\
\text { assessment }\end{array}$ & $\begin{array}{c}\text { Incomplete } \\
\text { outcome data } \\
\text { addressed } \\
\text { appropriately }\end{array}$ & $\begin{array}{c}\text { No } \\
\text { selective } \\
\text { reporting }\end{array}$ & $\begin{array}{c}\text { No other } \\
\text { sources } \\
\text { of bias }\end{array}$ & $\begin{array}{c}\text { Estimated } \\
\text { potential } \\
\text { risk of bias }\end{array}$ \\
\hline Mozzati et al. & Unclear & No & No & No & Unclear & Yes & Yes & High \\
\hline Haraji et al. & Unclear & No & Yes & No & Unclear & Yes & Yes & High \\
\hline Pal et al. & Unclear & No & Unclear & No & Unclear & Yes & Yes & High \\
\hline King et al. & Yes & Yes & No & Yes & Yes & Yes & Yes & High \\
\hline
\end{tabular}

Table 3: Results of studies included for analysis.

\begin{tabular}{|c|c|c|c|c|c|}
\hline Author & & Mozzati et al. & Haraji et al. & Pal et al. & King et al. \\
\hline \multirow[t]{6}{*}{ Pain (VAS) } & Day 1 & $\begin{array}{l}\text { G1: } \text { mean }=4.05(\#) \\
\text { G2: mean }=3.50(\#) \\
p>0.05\end{array}$ & $\mathrm{NE}$ & $\begin{array}{l}\mathrm{G} 1: 1.4 \pm 0.62 \\
\mathrm{G} 2: 5.2 \pm 1.24 \\
\boldsymbol{p}<\mathbf{0 . 0 0 1}\end{array}$ & $\mathrm{NE}$ \\
\hline & Day 2 & $\begin{array}{l}\text { G1: } \text { mean }=2.71(\#) \\
\text { G2: } \text { mean }=2.62(\#) \\
p>0.05\end{array}$ & $\begin{array}{l}\text { G1: } \text { mean }=2.77 \\
\text { G2: mean }=3.97 \\
\boldsymbol{p}<\mathbf{0 . 0 0}\end{array}$ & $\begin{array}{l}\text { G1: } 1.8 \pm 0.70 \\
\text { G2: } 5.7 \pm 0.94 \\
\boldsymbol{p}<\mathbf{0 . 0 0 1}\end{array}$ & $\mathrm{NE}$ \\
\hline & Day 3 & $\begin{array}{l}\mathrm{G} 1: \text { mean }=2.15(\#) \\
\mathrm{G} 2: \text { mean }=1.82(\#) \\
p>0.05\end{array}$ & $\begin{array}{l}\text { G1: } \text { mean }=2.09 \\
\text { G2: mean }=3.82 \\
\boldsymbol{p}<\mathbf{0 . 0 0}\end{array}$ & $\begin{array}{l}\mathrm{G} 1: 3.2 \pm 0.78 \\
\mathrm{G} 2: 5.7 \pm 0.94 \\
\boldsymbol{p}<\mathbf{0 . 0 0 1}\end{array}$ & $\begin{array}{l}\text { G1: } 4.0 \pm 2.7 \\
\text { G2: } 4.3 \pm 2.9 \\
p>0.05\end{array}$ \\
\hline & Day 4 & $\begin{array}{l}\mathrm{G} 1: \text { mean }=1.86(\#) \\
\mathrm{G} 2: \text { mean }=1.50(\#) \\
p>0.05\end{array}$ & $\begin{array}{l}\mathrm{G} 1: \text { mean }=1.69 \\
\mathrm{G} 2: \text { mean }=2.19 \\
\boldsymbol{p}<\mathbf{0 . 0 0}\end{array}$ & $\mathrm{NE}$ & $\mathrm{NE}$ \\
\hline & Day 5 & $\begin{array}{l}\mathrm{G} 1: \text { mean }=1.11(\#) \\
\mathrm{G} 2: \text { mean }=1.01(\#) \\
p>0.05\end{array}$ & $\mathrm{NE}$ & $\mathrm{NE}$ & $\mathrm{NE}$ \\
\hline & Day 6 & $\begin{array}{l}\mathrm{G} 1: \text { mean }=1.00(\#) \\
\mathrm{G} 2: \text { mean }=0.90(\#) \\
p>0.05\end{array}$ & $\mathrm{NE}$ & $\mathrm{NE}$ & $\mathrm{NE}$ \\
\hline
\end{tabular}


Table 3 cont: Results of studies included for analysis.

\begin{tabular}{|c|c|c|c|c|c|}
\hline & Day 7 & $\begin{array}{c}\mathrm{G} 1: \text { mean }=0.50(\#) \\
\mathrm{G} 2: \text { mean }=0.20(\#) \\
\boldsymbol{p}<\mathbf{0 . 0 5}\end{array}$ & NE & $\begin{array}{c}\text { G1: } 6.6 \pm 1.20 \\
\text { G2: } 5.7 \pm 0.94 \\
\boldsymbol{p}<\mathbf{0 . 0 1} \\
\end{array}$ & $\begin{array}{c}\text { G1: } 2.0 \pm 2.0 \\
\text { G2: } 2.4 \pm 2.6 \\
p>0.05 \\
\end{array}$ \\
\hline & Day 15 & $\mathrm{NE}$ & NE & $\begin{array}{c}\text { G1: } 6.6 \pm 1.20 \\
\text { G2: } 6.7 \pm 0.694 \\
p>0.05 \\
\end{array}$ & $\mathrm{NE}$ \\
\hline \multirow[t]{2}{*}{ Swelling } & Day 3 & $\mathrm{NE}$ & $\mathrm{NE}$ & $\mathrm{NE}$ & $\begin{array}{c}\text { G1: } 2.3 \pm 2.3 \\
\text { G2: } 2.9 \pm 2.7 \\
p>0.05\end{array}$ \\
\hline & Day 7 & $\mathrm{NE}$ & $\mathrm{NE}$ & $\mathrm{NE}$ & $\begin{array}{c}\text { G1: } 1.2 \pm 1.7 \\
\text { G2: } 1.8 \pm 1.8 \\
p>0.05\end{array}$ \\
\hline \multirow[t]{2}{*}{ Bleeding } & Day 3 & $\mathrm{NE}$ & $\mathrm{NE}$ & $\mathrm{NE}$ & $\begin{array}{c}\text { G1: } 0.9 \pm 1.2 \\
\text { G2: } 1.3 \pm 1.7 \\
p>0.05\end{array}$ \\
\hline & Day 7 & $\mathrm{NE}$ & $\mathrm{NE}$ & $\mathrm{NE}$ & $\begin{array}{c}\text { G1: } 0.4 \pm 0.6 \\
\text { G2: } 0.7 \pm 0.8 \\
p>0.05\end{array}$ \\
\hline \multirow[t]{2}{*}{ Bruising } & Day 3 & $\mathrm{NE}$ & $\mathrm{NE}$ & $\mathrm{NE}$ & $\begin{array}{c}\text { G1: } 1.7 \pm 2.4 \\
\text { G2: } 1.5 \pm 2.3 \\
p>0.05\end{array}$ \\
\hline & Day 7 & $\mathrm{NE}$ & $\mathrm{NE}$ & $\mathrm{NE}$ & $\begin{array}{c}\text { G1: } 1.3 \pm 2.3 \\
\text { G2: } 1.2 \pm 1.7 \\
p>0.05\end{array}$ \\
\hline \multirow[t]{2}{*}{$\begin{array}{l}\text { Inflammation } \\
\text { (clinical scoring) }\end{array}$} & Day 3 & ND & $\mathrm{NE}$ & $\mathrm{NE}$ & $\begin{array}{c}\text { G1: } 0.95 \pm 0.8 \\
\text { G2: } 1.33 \pm 0.7 \\
p>0.05 \\
\end{array}$ \\
\hline & Day 7 & ND & $\mathrm{NE}$ & $\mathrm{NE}$ & $\begin{array}{c}\mathrm{G} 1: 0.67 \pm 0.7 \\
\mathrm{G} 2: 1.19 \pm 0.8 \\
\boldsymbol{p}<\boldsymbol{0 . 0 5}\end{array}$ \\
\hline \multirow[t]{5}{*}{ Healing } & Day 1 & ND & $\mathrm{NE}$ & $\begin{array}{c}\text { G1: } 0.90 \pm 0.70 \\
\text { G2: } 0.20 \pm 0.15 \\
\boldsymbol{p}<\mathbf{0 . 0 0 1} \\
\end{array}$ & $\mathrm{NE}$ \\
\hline & Day 2 & ND & $\mathrm{NE}$ & $\begin{array}{c}\text { G1: } 1.20 \pm 0.94 \\
\text { G2: } 0.40 \pm 0.20 \\
\boldsymbol{p}<\mathbf{0 . 0 0 1} \\
\end{array}$ & $\mathrm{NE}$ \\
\hline & Day 3 & ND & $\begin{array}{c}\mathrm{G} 1: \text { mean }=2.52 \\
\mathrm{G} 2: \text { mean }=4.07 \\
\boldsymbol{p}<\mathbf{0 . 0 0}\end{array}$ & $\begin{array}{c}\text { G1: } 1.60 \pm 0.82 \\
\text { G2: } 0.60 \pm 0.36 \\
\boldsymbol{p}<\mathbf{0 . 0 0 1} \\
\end{array}$ & $\begin{array}{c}\text { G1: } 5.6 \pm 2.1 \\
\text { G2: } 5.4 \pm 2.9 \\
p>0.05 \\
\end{array}$ \\
\hline & Day 7 & ND & $\begin{array}{c}\mathrm{G} 1: \text { mean }=0.66 \\
\mathrm{G} 2: \text { mean }=0.95 \\
\boldsymbol{p}<\mathbf{0 . 0 0}\end{array}$ & $\begin{array}{c}\mathrm{G} 1: 2.20 \pm 0.92 \\
\mathrm{G} 2: 1.00 \pm 0.42 \\
\boldsymbol{p}<\mathbf{0 . 0 0 1} \\
\end{array}$ & $\begin{array}{c}\text { G1: } 6.7 \pm 2.7 \\
\text { G2: } 5.6 \pm 2.9 \\
p>0.05 \\
\end{array}$ \\
\hline & Day 15 & $\mathrm{NE}$ & NE & $\begin{array}{c}\text { G1: } 2.70 \pm 0.60 \\
\text { G2: } 2.60 \pm 0.62 \\
p>0.05 \\
\end{array}$ & $\mathrm{NE}$ \\
\hline \multirow[t]{2}{*}{$\begin{array}{l}\text { Exposed bone (\% } \\
\text { of patients) }\end{array}$} & Day 3 & $\mathrm{NE}$ & NE & NE & $\begin{array}{l}\text { G1: } 9.1 \\
\text { G2: } 9.1 \\
p>0.05\end{array}$ \\
\hline & Day 7 & NE & $\mathrm{NE}$ & NE & $\begin{array}{c}\mathrm{G} 1: 0 \\
\mathrm{G} 2: 22.7 \\
\boldsymbol{p}<\boldsymbol{0 . 0 5}\end{array}$ \\
\hline \multirow[t]{2}{*}{$\begin{array}{l}\text { Halitosis } \\
\text { ( } \% \text { of patients) }\end{array}$} & Day 3 & $\mathrm{NE}$ & $\mathrm{NE}$ & NE & $\begin{array}{l}\text { G1: } 33.3 \\
\text { G2: } 40.9 \\
p>0.05\end{array}$ \\
\hline & Day 7 & NE & $\mathrm{NE}$ & NE & $\begin{array}{c}\mathrm{G} 1: 9.1 \\
\mathrm{G} 2: 42.9 \\
\boldsymbol{p}<\boldsymbol{0 . 0 5}\end{array}$ \\
\hline \multirow[t]{2}{*}{$\begin{array}{l}\text { Dysgeusia } \\
\text { ( } \% \text { of patients) }\end{array}$} & Day 3 & NE & $\mathrm{NE}$ & NE & $\begin{array}{l}\text { G1: } 47.6 \\
\text { G2: } 68.2 \\
p>0.05\end{array}$ \\
\hline & Day 7 & NE & $\mathrm{NE}$ & NE & $\begin{array}{l}\text { G1: } 27.3 \\
\text { G2: } 42.9 \\
p>0.05\end{array}$ \\
\hline $\begin{array}{l}\text { Incidence of dry } \\
\text { socket }\end{array}$ & & NE & $\begin{array}{c}4 \text { cases in G1 } \\
18 \text { cases in G2 } \\
\boldsymbol{p}<\mathbf{0 . 0 5}\end{array}$ & NE & $\mathrm{NE}$ \\
\hline
\end{tabular}

VAS=visual analogue scale; (\#)=the data was estimated from the figure; NE=not evaluated; G1,G2,G3=illustration same as Table 1. 
Alveolar fossa healing

During the $7 \mathrm{~d}$ follow-up periods, Haraji et al. and Pal et $a l$. found that the healing of the PRGF group was faster than that of the corresponding control group with $p$ value $<0.001$. However, no statistical difference was found in the study by King et al. As the postoperative time was prolonged to $15 \mathrm{~d}$, the Pal et al reported there is no difference in healing values between groups.

\section{Inflammation}

King et al. indicated that at $7 \mathrm{~d}$ clinical inflammation was significantly lower in patients in the PRGF® group compared to the Alvogyl ${ }^{\circledR}$ group. Whereas these differences were not significant at $3 \mathrm{~d}$.

The incidence of dry socket

Haraji et al. evaluated the incidence of dry socket. In the control group, 18 patients presented dry socket. Four patients developed dry socket in PRGF group. This was indicative of a statistically significant difference when PRGF was used $(p<0.05)$.

\section{Discussion}

PRGF was used in various types of surgery in oral and maxillofacial surgery. These procedures included series of complicated surgery such as the tooth extraction socket filling (38-40), maxillary sinus augmentation (41), and maxillofacial bone defects $(42,43)$. It has been reported that the use of PRGF can reduce postoperative pain and inflammatory response, accelerate epithelial formation of soft tissue and promote regeneration of bone tissue $(44,45)$.

The purpose of this review is to evaluate the efficacy of PRGF used in the dry socket management following the third molars extraction, further to provide scientific evidence for clinical applications. Although many scholars praised the benefits of PRGF clinical application in many fields, few clinical trials have been conducted to investigate the effect of PRGF on dry socket treatment after tooth extractions, especially randomized controlled trials. Four randomized controlled trials $(12,26,34,35)$ on this topic was retrieved into this review, of which only one article meet the high quality (35) standards of the modified Jadad scale (36) and the remaining three $(12,26,34)$ were low quality. In addition, obvious heterogeneity were found in the method adopted and outcome variables used in the process of evaluation of the healing of dry socket. A quantitative meta-analysis cannot be performed in this case and we could only do a qualitatively descriptive study on the subject.

One possible factor amongst many confounding factors in this systematic review is the choice of indications for extraction. If the teeth were extracted for different reasons such as impact, trauma, periodontitis or periapical infection, the healing process may be different. A histological study (46), conducted for nearly two years, found that the speed of bone formation in the diseased sockets were more slowly than that in the disease-free sockets. New bone area exceeded $50 \%$ of the total newly regenerated tissue in the infected sockets after 16 weeks, whereas new bone area in the disease-free sockets exceeded $50 \%$ of the total tissue. However, a retrospective chart review by Bell et al. (47) demonstrated that clinical attempt to place implant in the extraction socket in the presence of chronic apical periodontitis can be regarded as a safe and feasible treatment option. It is well known that the healing of the impacted third molars with soft tissue resistance would be better than that with bone tissue resistance.

Another confounding factor could be the types of protocol for acquiring PRGF preparations among different studies. Currently, there are many different methods proposed for the preparation of PRGF products. The core aim of different technique used to obtain PRGF was to produce a leukocyte-free preparation so as to reduce the content of pro-inflammatory cytokines. Some of the four included studies did not provide a detailed description of a series of parameters involving in the PRGF production preparation process (cell separators used, centrifugation methods, blood volume collected before surgery, collected the platelet baseline concentration, the amount of platelet concentrate obtained, the final increase in platelet concentration, the type of blood anticoagulant and platelet activator used). Any of these factors may play a role in the vitality and activity of the tissue. Different concentrations and levels of PRGF may have different biological properties.

There are some limitations for this systematic review: 1- the search process led to the inclusion of only four articles, the number of which was too small. In addition, the number of patients included in the study was small, result of which may be partial bias. 2- the included studies did not perform well in random sequences generation, allocation concealment and blinded methods, as these are important for RCTs. Furthermore, there was no multicenter randomized controlled studies. 3- there are no specific diagnostic criteria for dry socket in these studies. 4- oral contraceptive use (48) and tobacco smoking (49) may influence the incidence of dry socket, but he included studies did not handle these two confounding factors.

In summary, meta-analysis cannot be performed given the heterogeneity of the outcome variables included in the different studies. According to results from selected studies, the use of PRGF may help reduce pain and inflammation after tooth extraction, thereby improving the quality of life of patients after tooth extraction. However, after evaluating quality of the included articles, we found that the evidence quality of PRGF applied to the dry socket management after the third tooth extractions was poor, so it was impossible to make a recommen- 
dation for clinical use of PRGF. Clearly, a multicenter clinical randomized controlled trial is needed to urgent conduct to evaluate the safety and efficacy of PRGF for dry socket management after mandibular third molar extraction.

\section{References}

1. Bui CH, Seldin EB, Dodson TB. Types, frequencies, and risk factors for complications after third molar extraction. J Oral Maxillofac Surg. 2003;61:1379-89.

2. Larsen PE. Alveolar osteitis after surgical removal of impacted mandibular third molars. Identification of the patient at risk. Oral Surg Oral Med Oral Pathol. 1992;73:393-97.

3. Parthasarathi K, Smith A, Chandu A. Factors affecting incidence of dry socket: a prospective community-based study. J Oral Maxillofac Surg. 2011;69:1880-84.

4. Blum IR. Contemporary views on dry socket (alveolar osteitis): a clinical appraisal of standardization, aetiopathogenesis and management: a critical review. Int J Oral Maxillofac Surg. 2002;31:309-17. 5. Hasheminia D, Moaddabi A, Moradi S, Soltani P, Moannaei M, Issazadeh $\mathrm{M}$. The efficacy of $1 \%$ Betadine mouthwash on the incidence of dry socket after mandibular third molar surgery. J Clin Exp Dent. 2018;10:e445-49.

6. Fotos PG, Koorbusch GF, Sarasin DS, Kist RJ. Evaluation of intraalveolar chlorhexidine dressings after removal of impacted mandibular third molars. Oral Surg Oral Med Oral Pathol. 1992;73:383-88.

7. Hermesch CB, Hilton TJ, Biesbrock AR, Baker RA, Cain-Hamlin $\mathrm{J}$, McClanahan SF, et al.. Perioperative use of $0.12 \%$ chlorhexidine gluconate for the prevention of alveolar osteitis: efficacy and risk factor analysis. Oral Surg Oral Med Oral Pathol Oral Radiol Endod. 1998;85:381-87.

8. Oginni FO, Fatusi OA, Alagbe AO. A clinical evaluation of dry socket in a Nigerian teaching hospital. J Oral Maxillofac Surg. 2003;61:871-76.

9. Nusair YM, Younis MH. Prevalence, clinical picture, and risk factors of dry socket in a Jordanian dental teaching center. J Contemp Dent Pract. 2007;8:53-63.

10. Chaurasia NK, Upadhyaya C, Dixit S. Comparative Study to Determine the efficacy of Zinc Oxide Eugenol and Alveogyl in Treatment of Dry Socket. Kathmandu Univ Med J (KUMJ). 2017;15:203-06.

11. Aleman NR, Martinez MM. Case report: late complication of a dry socket treatment. Int J Dent. 2010;2010:479306.

12. Pal US, Singh BP, Verma V. Comparative evaluation of zinc oxide eugenol versus gelatin sponge soaked in plasma rich in growth factor in the treatment of dry socket: An initial study. Contemp Clin Dent. 2013;4:37-41.

13. Lone PA, Ahmed SW, Prasad V, Ahmed B. Role of turmeric in management of alveolar osteitis (dry socket): A randomised clinical study. J Oral Biol Craniofac Res. 2018;8:44-7.

14. Gupta A, Rattan V, Rai S. Efficacy of Chitosan in promoting wound healing in extraction socket: A prospective study. J Oral Biol Craniofac Res. 2019;9:91-5.

15. Nishio C, Rompre P, Moldovan F. Effect of exogenous retinoic acid on tooth movement and periodontium healing following tooth extraction in a rat model. Orthod Craniofac Res. 2017;20 Suppl 1:77-82.

16. Soni N, Singh V, Mohammad S, Singh RK, Pal US, Singh R, et al.. Effects of honey in the management of alveolar osteitis: A study. Natl J Maxillofac Surg. 2016;7:136-47.

17. Singh V, Pal US, Singh R, Soni N. Honey a sweet approach to alveolar osteitis: A study. Natl J Maxillofac Surg. 2014;5:31-4. 18. Isola G, Matarese M, Ramaglia L, Iorio-Siciliano V, Cordasco G, Matarese G. Efficacy of a drug composed of herbal extracts on postoperative discomfort after surgical removal of impacted mandibular third molar: a randomized, triple-blind, controlled clinical trial. Clin Oral Investig. 2019;23(5):2443-53.

19. Osborn TP, Frederickson GJ, Small IA, Torgerson TS. A prospective study of complications related to mandibular third molar surgery. J Oral Maxillofac Surg. 1985;43:767-69.
20. Del FM, Corbella S, Taschieri S, Francetti L, Weinstein R. Autologous platelet concentrate for post-extraction socket healing: a systematic review. Eur J Oral Implantol. 2014;7:333-44.

21. Del FM, Bortolin M, Taschieri S. Is autologous platelet concentrate beneficial for post-extraction socket healing? A systematic review. Int J Oral Maxillofac Surg. 2011;40:891-900.

22. Anitua E, Alkhraisat MH, Orive G. Perspectives and challenges in regenerative medicine using plasma rich in growth factors. J Control Release. 2012;157:29-38.

23. Anitua E, Sanchez M, Aguirre JJ, Prado R, Padilla S, Orive G. Efficacy and safety of plasma rich in growth factors intra-articular infiltrations in the treatment of knee osteoarthritis. Arthroscopy. 2014;30:1006-17.

24. Anitua E. Plasma rich in growth factors: preliminary results of use in the preparation of future sites for implants. Int J Oral Maxillofac Implants. 1999;14:529-35

25. Mansouri SS, Ghasemi M, Darmian SS, Pourseyediyan T. Treatment of Mandibular Molar Class II Furcation Defects in Humans with Bovine Porous Bone Mineral in Combination with Plasma Rich in Growth Factors. J Dent (Tehran). 2012;9:41-9.

26. Mozzati M, Martinasso G, Pol R, Polastri C, Cristiano A, Muzio $\mathrm{G}$, et al.. The impact of plasma rich in growth factors on clinical and biological factors involved in healing processes after third molar extraction. J Biomed Mater Res A. 2010;95:741-46.

27. Quesada-Garcia MP, Prados-Sanchez E, Olmedo-Gaya MV, Munoz-Soto E, Vallecillo-Capilla M, Bravo M. Dental implant stability is influenced by implant diameter and localization and by the use of plasma rich in growth factors. J Oral Maxillofac Surg. 2012;70:276167.

28. Anitua E, Prado R, Orive G. Bilateral sinus elevation evaluating plasma rich in growth factors technology: a report of five cases. Clin Implant Dent Relat Res. 2012;14:51-60.

29. Del FM, Boggian C, Taschieri S. Immediate implant placement into fresh extraction sites with chronic periapical pathologic features combined with plasma rich in growth factors: preliminary results of single-cohort study. J Oral Maxillofac Surg. 2009;67:2476-84.

30. Taschieri S, Corbella S, Tsesis I, Del FM. Impact of the use of plasma rich in growth factors (PRGF) on the quality of life of patients treated with endodontic surgery when a perforation of sinus membrane occurred. A comparative study. Oral Maxillofac Surg. 2014;18:43-52

31. Anitua E, Murias-Freijo A, Alkhraisat MH, Orive G. Clinical, radiographical, and histological outcomes of plasma rich in growth factors in extraction socket: a randomized controlled clinical trial. Clin Oral Investig. 2015;19:589-600.

32. Anitua E, Alonso R, Girbau C, Aguirre JJ, Muruzabal F, Orive G. Antibacterial effect of plasma rich in growth factors (PRGF(R)Endoret(R)) against Staphylococcus aureus and Staphylococcus epidermidis strains. CLIN EXP DERMATOL. 2012;37:652-57.

33. Drago L, Bortolin M, Vassena C, Taschieri S, Del FM. Antimicrobial activity of pure platelet-rich plasma against microorganisms isolated from oral cavity. BMC Microbiol. 2013;13:47.

34. Haraji A, Lassemi E, Motamedi MH, Alavi M, Adibnejad S. Effect of plasma rich in growth factors on alveolar osteitis. Natl J Maxillofac Surg. 2012;3:38-41.

35. King EM, Cerajewska TL, Locke M, Claydon N, Davies M, West NX. The Efficacy of Plasma Rich in Growth Factors for the Treatment of Alveolar Osteitis: A Randomized Controlled Trial. J Oral Maxillofac Surg. 2018;76:1150-59.

36. Moher D, Liberati A, Tetzlaff J, Altman DG. Preferred reporting items for systematic reviews and meta-analyses: the PRISMA statement. BMJ. 2009;339:b2535.

37. Landis JR, Koch GG. The measurement of observer agreement for categorical data. Biometrics. 1977;33:159-74

38. Samandari MH, Haghighat A, Torabinia N, Taghian M, Sadri L, Naemy V. Socket preservation using freeze-dried bone allograft with and without plasma rich in growth factors in dogs. Dent Res J (Isfahan). 2016;13:432-39.

39. Anitua E, Murias-Freijo A, Alkhraisat MH, Orive G. Clinical, 
radiographical, and histological outcomes of plasma rich in growth factors in extraction socket: a randomized controlled clinical trial. Clin Oral Investig. 2015;19:589-600.

40. Nazaroglou I, Stavrianos C, Kafas P, Matoulas E, Upile T, Barlas I, et al.. Radiographic evaluation of bone regeneration after the application of plasma rich in growth factors in a lower third molar socket: a case report. Cases J. 2009;2:9134.

41. Taschieri S, Corbella S, Del FM. Use of plasma rich in growth factor for schneiderian membrane management during maxillary sinus augmentation procedure. J Oral Implantol. 2012;38:621-27.

42. Paknejad M, Shayesteh YS, Yaghobee S, Shariat S, Dehghan M, Motahari P. Evaluation of the Effect of Plasma Rich in Growth Factors (PRGF) on Bone Regeneration. J Dent (Tehran). 2012;9:59-67.

43. Molina-Minano F, Lopez-Jornet P, Camacho-Alonso F, VicenteOrtega V. Plasma rich in growth factors and bone formation: a radiological and histomorphometric study in New Zealand rabbits. Braz Oral Res. 2009;23:275-80.

44. Anitua E, Troya M, Orive G. Plasma rich in growth factors promote gingival tissue regeneration by stimulating fibroblast proliferation and migration and by blocking transforming growth factor-beta1-induced myodifferentiation. J Periodontol. 2012;83:1028-37.

45. Anitua E, Tejero R, Zalduendo MM, Orive G. Plasma rich in growth factors promotes bone tissue regeneration by stimulating proliferation, migration, and autocrine secretion in primary human osteoblasts. J Periodontol. 2013;84:1180-90.

46. Ahn JJ, Shin HI. Bone tissue formation in extraction sockets from sites with advanced periodontal disease: a histomorphometric study in humans. Int J Oral Maxillofac Implants. 2008;23:1133-38.

47. Bell CL, Diehl D, Bell BM, Bell RE. The immediate placement of dental implants into extraction sites with periapical lesions: a retrospective chart review. J Oral Maxillofac Surg. 2011;69:1623-27.

48. Xu JL, Sun L, Liu C, Sun ZH, Min X, Xia R. Effect of oral contraceptive use on the incidence of dry socket in females following impacted mandibular third molar extraction: a meta-analysis. Int $\mathbf{J}$ Oral Maxillofac Surg. 2015;44:1160-5.

49. Rakhshan V. Common risk factors of dry socket (alveolitis osteitis) following dental extraction: A brief narrative review. J Stomatol Oral Maxillofac Surg. 2018;119:407-11.

\section{Funding}

The project was supported by Anhui Province Key Laboratory of Medical Physics and Technology [Grant no. LMPT201707] and Anhui Province Natural Science Foundation [Grant no. 1508085MH156].

Conflict of interest

The authors have declared that no conflict of interest exist. 